\title{
China-Myanmar Cross-border Agricultural Economic Cooperation - Views from Myanmar
}

\author{
Pei Mao ${ }^{1}$ Yan Zhang ${ }^{1, *}$ Lu Feng $^{1}$ Pau Sian Kam ${ }^{1}$ \\ ${ }^{1}$ Yunnan Agricultural University, Kunming, Yunnan 650201, China \\ *Corresponding author. Email: fenglu1128@126.com
}

\begin{abstract}
Objective: Based on the Yunnan-Myanmar agricultural cooperation, this article explores coordinated policies to promote China-Myanmar cross-border agricultural economic cooperation. Method: Taking the official statistical data of Myanmar as evidence, this paper analyzes the Myanmar-China cross-border agricultural trade from the international trade float of Myanmar, and compares the deficit status, government consensus, investment and construction of the cross-border trade between Myanmar and China among the trading partners of Myanmar, and further analyzes the important role of cross-border agricultural economic cooperation between Myanmar and China. Result: The study shows that China is the largest trading partner of Myanmar, and the agricultural products is one of the main foreign exchange products that Myanmar exports to China, and China has been actively carrying out trade measures to promote agricultural economic cooperation. Meanwhile, Myanmar indicates that it is urgent to narrow the trade deficit, by improving the quality standardization of agricultural products, strengthening the construction of border ports and sharing information in bilateral markets. Suggestion: As the main carrier of Myanmar-China economic cooperation, Yunnan should strengthen China-Myanmar crossborder agricultural economic cooperation by enhancing and improving the trade of agricultural products between Yunnan and Myanmar.
\end{abstract}

Keywords: International trade, Agricultural economic cooperation, Cross-border areas, Myanmar.

\section{INTRODUCTION}

Cross-border economic cooperation is an important form of international cooperation. In today's society where the degree of world integration is getting higher and higher, the research on cross-border regions and cross-border effects is attracting more and more research in the fields of politics, economy, society and other disciplines, and has become an important topic of global economic development (Niebuhr, 2002). In the 1990s, the east and west of Europe carried out large-scale and intensive cross-border regional integration, At present, there are more than 70 cross-border regions in Europe, whose prosperity and development are not only supported by the EU policy, but also subject to the administrative supervision of multiple departments. Moreover, the development forms and cooperation modes of

*Fund: Research on agricultural development in Myanmar and cooperation between Myanmar and China supported by Yuntianhua Group. cross-border regions are diversified (Perkmann, 2003). At present, there are two main theories to analyze the obstacles to cross-border economic development. One is to analyze the decisionmaking activities of micro-economic participants supported by industrial organization theory, and the other is to examine the specific background and space of bilateral development from the perspective of regional economic development (Ratti and Reichman, 1993). For cross-border economic development to succeed, it requires not only a government consensus on cross-border development issues, but also the support of the direct players, namely production organizers such as companies (Tsuneishi, 2008; Li et al, 2016). Cross-border cooperation can boost the economic development of every participating country in the region, it depends on the depth of relations between the neighbors. It is based on the common interest of improving living standards, ensuring a sustainable and harmonious framework and removing border barriers, restrictions or other factors. Local 
communities are increasingly involved in regional cooperation in order to improve the socioeconomic status of regional communities and to eliminate the negative effects of borders (Marcela Şlusarciuc, 2015). Based on the data of 199 cross-border cities in China, the results show that China's cross-border regions face high cross-border effects when participating in international trade and cross-border cooperation, and there are significant differences between different distances and different crossborder regions. Among them, geography, infrastructure, economic development and policies all have an impact on the opening up and regional cooperation of China's cross-border areas. As the only important node of "One Belt And One Road" connecting South Asian countries, Myanmar enjoys a rapid development momentum due to its unique regional characteristics and resource advantages. Chinese scholars learned from venture capital (OUYANG Biyuan, 2016), industry cooperation (WANG Jiajie, 2018), the population management (FENG Jie, 2019), especially cooperation in agricultural science and technology (LIU Zuxin, 2015; WEN Guoquan, 2019) and agricultural products trade (LIU Wu \& JIN Liping, 2016) etc.carried out research on China-Myanmar cooperation and believed that the potential of cooperation is becoming increasingly prominent. Based on the development trend of Myanmar's international trade and the cooperation of YunnanMyanmar agricultural science and technology, this paper analyzes the main concerns in Sino-Myanmar agricultural economic cooperation and discusses the countermeasures. China-Myanmar cross-border cooperation research should further seize the new opportunities of current international cooperation, strengthen cooperation in agricultural science and technology to develop agricultural economy and trade economy, more importantly, both sides should further enhance their own research and thinking on cross-border cooperation, and listen to more voices from Myanmar in particular, therefore, targeted countermeasures and suggestions are put forward to guide the sustainable development of ChinaMyanmar cross-border agricultural economic cooperation.

\section{MYANMAR INTERNATIONAL TRADE}

China's cross-border economic cooperation needs to strengthen the strength of the cooperation itself and the communication between the two regions, therefore, the author took CNKI Scholar database as the source, selected "China Myanmar" as the subject term, "Trade Economy" and "Agricultural Economy" as the subject area. After consulting the international core journals from 2009 to 2019 , the author obtained a total of 93 valid data, accounting for $43 \%$ of the researches on China and Myanmar. However, according to the abstracts, the author selected 30 articles with high correlation, which showed that $7 \%$ were from ASEAN institutions, $40 \%$ from Chinese institutions, and $53 \%$ from European and American institutions, indicating that we need to further strengthen the research strength of Sino-Myanmar agricultural economic cooperation. Therefore, this paper summarizes the views of Myanmar based on the official statistics of Myanmar, and thus interprets the cross-border agricultural and economic cooperation between China and Myanmar. Myanmar's statistical fiscal year runs from April to March of each year. The sources cited in this article are official statistics from the Ministry of Commerce, Republic of the Union of Myanmar.

\subsection{The Fluctuation of International Trade Highlights the Importance of Cross- border Trade}

Myanmar is located in southeast Asia and west of Indo-China Peninsula, with an area of about 678,500 square kilometers and a coastline of 3,200 kilometers. The capital is Naypyidaw. In the 20172018 fiscal year, Myanmar's GDP was about \$69 billion, or about $\$ 1,300$ per capita, attracting $\$ 5.8$ billion in foreign direct investment. Its economic development is mainly based on agriculture, but due to the single structure of agricultural products, weak foundation and low level of development, its economic development has been slow for many years. Although it is a member of ASEAN, it is also one of the least developed countries in the world.

Myanmar's international trade can be divided into normal trade (maritime trade) and cross-border trade. All international trade is controlled by the government, and normal trade volume is usually greater than cross-border trade volume. Although trade policy is aimed at liberalizing markets, it remains unpredictable due to the changing direction of policy and political instability in Myanmar1. At the same time, because of smuggled into Thailand, China, Bangladesh, Malaysia and India trade in goods value is difficult to estimate, such as timber

1. https://www. commerce. gov. $\mathrm{mm} / \mathrm{my} / \mathrm{dobt} /$ article/sixth-myanmar-china-joint-border- tradecoordinating-and-cooperating-committee-meeting-was Ministry of Commerce, Republic of the Union of Myanmar 
and stones, and imports of textiles, consumer goods, petroleum products, machinery and equipment, building materials, crude oil, edible oil and other products import value is significantly undervalued, imports and exports are undervalued 2. Myanmar's total trade increased significantly in the 2014-2017 fiscal year, with trade totalling \$24 billion in the 2016-2017 fiscal year ("Figure 1"). In 2018, the situation in the Kokang region of Shan State seriously affected the cross-border trade between Myanmar and China, resulting in a significant decline in the total border trade and a serious deficit in the import and export trade, with imports more than doubling the volume of exports 3.

\subsection{Agricultural Trade Deficit Reflects the Passivity of International Trade}

Myanmar is an agricultural country, with agriculture contributing $42 \%$ of its GDP. It is not only the food base of the country, but also the main source of industrial raw materials. It also provides employment opportunities for more than $60 \%$ of the labor force. Myanmar has huge potential for land and water under different weather and soil conditions. Myanmar agriculture (crop) net planting area of 12.1 million hectares (17.7\%), there are lots of land for cultivation, and other protection forests (27. $4 \%$ ), other forest land 18.55 million hectares, 14.74 million hectares (21. 8\%), water and other land 16.66 million hectares (24. 6\%), farming land 5.25 million hectares (7. 8\%), and fallow fields 450000 hectares $(0.7 \%) 4$. The main types of crops in Myanmar are rice, beans, oilseeds, corn, wheat and other cereals, as well as sesame, rubber, coffee, tea, sugar cane, jute, cotton, pepper, oil palm, and various herbs, fruits and vegetables.

From the fiscal year 2000-2001 to the fiscal year 2015-2016, the total value of Myanmar's agricultural exports rose from US $\$ 360$ million to US $\$ 1.22$ billion. Among them, the total export of beans has been about $70 \%$, and the total export of rice is only about $13 \%$. Although the total value of agricultural exports has continued to rise, the share of agricultural exports in international trade has

2. https://www. commerce. gov. mm/en/dobt/bordertrade-data? Ministry of Commerce, Republic of the Union of Myanmar

3. Ministry of Commerce, Republic of the Union of Myanmar https://www. commerce. gov. $\mathrm{mm} / \mathrm{en} / \mathrm{dot} /$ article/trade-and-investment-opportunity

4. Myanmar Agriculture at a Glance, 2017. Ministry of Agriculture, Livestock and Irrigation, Myanmar https://en. wikipedia. org/wiki/Economy_of_Myanmar declined from $18.2 \%$ to $9.9 \%$, as Myanmar's natural gas exports have increased from $8 \%$ to $30 \%$. The total amount of agricultural products imported by Myanmar rose from 150 million US dollars to 1.576 billion US dollars, and the proportion of agricultural products import in international trade rose from $3.9 \%$ to $9.3 \%$. Nearly half of the imported agricultural products were fresh vegetables, followed by condensed milk, flour, tobacco and tea. Therefore, Myanmar's international trade of agricultural products not only presents a trend of trade deficit in terms of amount, but also the proportion of total imports of agricultural products continues to increase and the proportion of total exports continues to decline ("Figure 2"). Myanmar's main export agricultural products are basic food consumer goods, while its imports are mostly non-staple food products. Myanmar's agricultural international trade is still in a relatively passive and low-level form. 


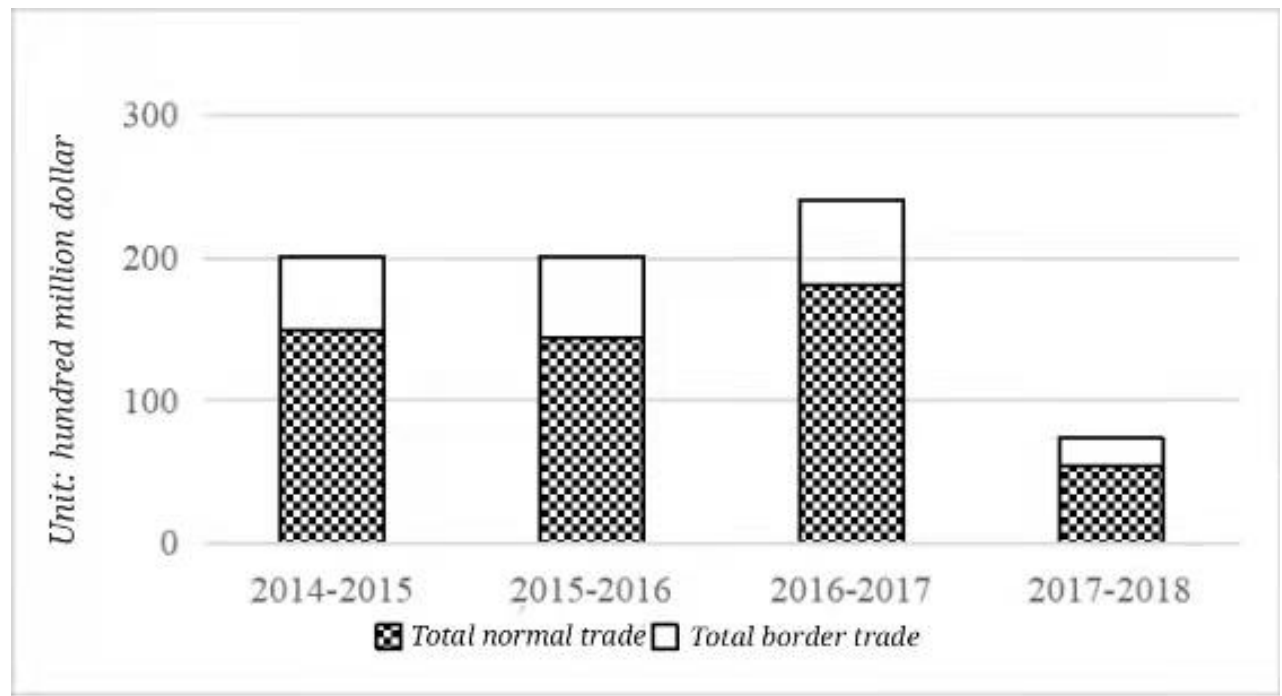

Figure 1 Normal and border trade in Myanmar (2014-2018).

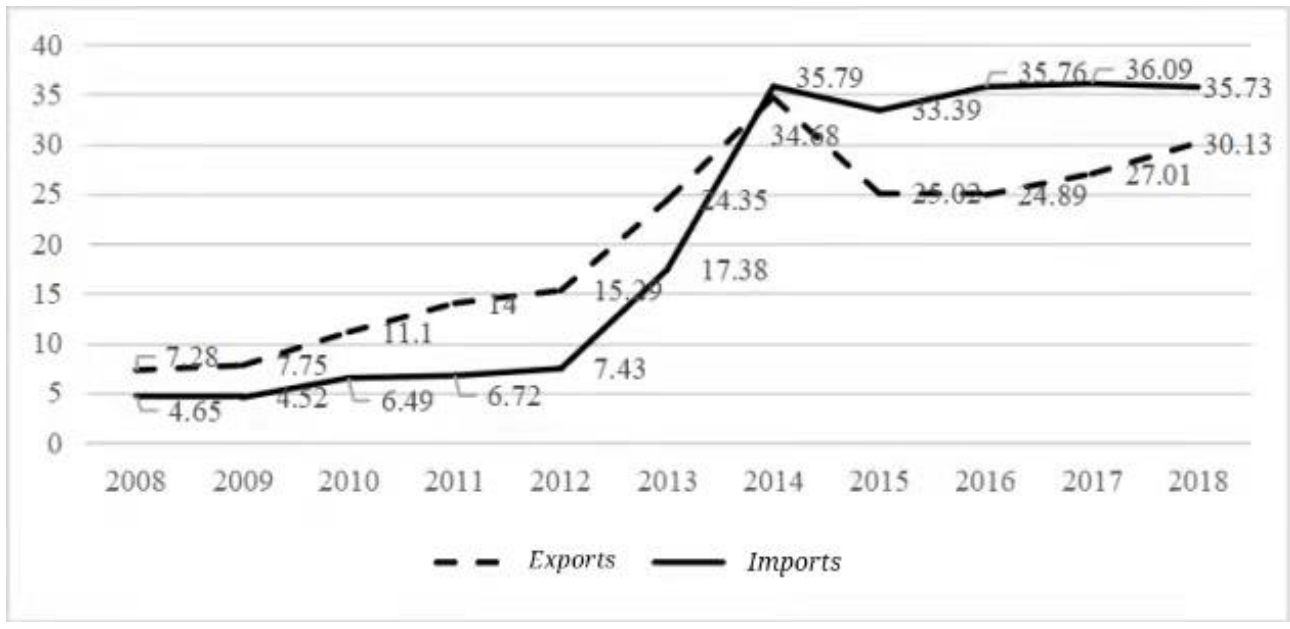

Figure 2 Total import and export volume of agricultural products in Myanmar (2000-2016).

\section{CROSS-BORDER}

\section{AGRICULTURAL AND ECONOMIC COOPERATION BETWEEN MYANMAR AND CHINA}

On July 20, 2018, the 9th Council of the Agricultural Science and Technology Exchange and Cooperation Group of the Greater Mekong Subregion was held in Baoshan, Yunnan Province. As the host of the 4th Group Meeting of the Working Group on Agricultural Economy, the author communicated with representatives of the Department of Agricultural Research of the Ministry of Agriculture, Animal Husbandry and Irrigation of Myanmar on the theme of ChinaMyanmar cross-border agricultural economic construction. On August 2, 2019, the Notice of the
State Council on Printing and Isending the General Plan of Six New Pilot Free Trade Zones was issued and implemented, and the China (Yunnan) Pilot Free Trade Zone was officially established. Among them, Dehong Area is mainly designed to be a pioneer zone for opening up along the border and a gateway hub for the China-Myanmar Economic Corridor. The two sides took this opportunity to continue to conduct exchanges on cross-border economic cooperation under the China-Myanmar Economic Corridor. On December 1, 2020, the "China-Myanmar Agricultural Science and Technology Cooperation Online Forum" was held in Kunming, Yunnan Province, to discuss the process of China-Myanmar agricultural science and technology cooperation during the epidemic of COVID-19. 


\subsection{Myanmar Runs a Trade Deficit in Cross-Border Trade}

Trade with the U.S. and Europe has been declining since the democracy movement in 1988. More than 80 percent of Myanmar's imports and exports are with Asian countries, and ASEAN countries account for about half of the country's total international trade5. The main export partners are China, Thailand, India, Japan and Singapore. The main import partners are, in that order, China, which accounts for a third of Myanmar's international trade, followed by Singapore, Thailand, Japan and India ("Figure 3").

In the past five years, China, Thailand and India have been the main partners in Myanmar's international trade, but their share varies greatly. The international trade between Myanmar and China is mainly cross-border trade, accounting for $79 \%$ of the total cross-border trade of Myanmar; Thailand was second with more than $20 \%$. India's share is more than 1\%; Bangladesh accounts for less than 1\%. Cross-border trade between Myanmar and China reached 5.967 billion US dollars in the 2016-2017 fiscal year, an increase of 30 million US dollars over 5.936 billion US dollars in the 20152016 fiscal year. In the 2017-2018 fiscal year, the total trade volume between Myanmar and China reached US $\$ 21.8$ billion, with exports and imports accounting for $68.4 \%$ and $31.6 \%$ respectively (Koji KUBO, 2016). Myanmar's cross-border trade is mainly dominated by China. Myanmar exports and imports many products from China.

\subsection{The Governments of Myanmar and China Reached Consensus on Cross- border Agricultural and Economic Cooperation}

On April 29, 2011, the 6th Myanmar-China Joint Committee on Cross-border Trade Cooperation was held in Muse, Shan State, northern Myanmar. The two sides agreed to promote bilateral trade and open cross-border agricultural and economic cooperation. Agricultural cooperation is mainly covered in the following four areas:

5. Review on the Present State of Food and Agricultura Statistic. In Myanmar http://www. fao.

org/fileadmin/templates/ess/documents/meetings_and_workshop s/ APCAS23/documents_OCT10/APCAS-10-11_-

Myanmar_Ctry_report. $\mathrm{doc}$

\subsubsection{Tariffs and Quotas on Agricultural Products}

Myanmar's two proposals concerning the removal of tariffs and quota-free market access for agricultural products destined for the Chinese market, and the removal or increase of export quotas for maize and rubber grown as substitutes in Kachin State and Shan State. Yunnan Provincial Department of Commerce informed the Myanmar side of the provisions on normal quota-free market access for agricultural products stipulated in the China-ASEAN Free Trade Agreement, and suggested that Myanmar formally apply to the General Administration of Quality, meanwhile, in order to further expand the export of agricultural products to the Chinese market, the relevant products are subject to risk assessment by the Chinese supervision, Inspection and Quarantine Authorities.

\subsubsection{Regional Tax Differences}

With regard to Myanmar's proposal to reduce the difference in local taxes levied by Yunnan Province compared to other provinces (regions) of China, the Yunnan Provincial Department of Commerce has agreed to review the matter and find out the differences, while promising that Yunnan Province can also implement the local tax structure levied by other provinces and regions.

\subsubsection{Cross-border Trade Market}

The two sides recognize the importance of commodity quality and fair prices to ensure a sustainable market, and stand ready to provide assistance to businesses of both sides through the Trade Promotion Platform to ensure smoother and more convenient trade. The two sides acknowledged that illegal trade impedes the development of normal trade and agreed that relevant authorities of the two countries should cooperate to prevent smuggling trade. China proposed to increase the number of border trade ports designated by the Myanmar government to effectively curb illegal trade, and agreed to cooperate with Myanmar to guide Chinese enterprises to carry out activities at border trade ports designated by the Myanmar government. 


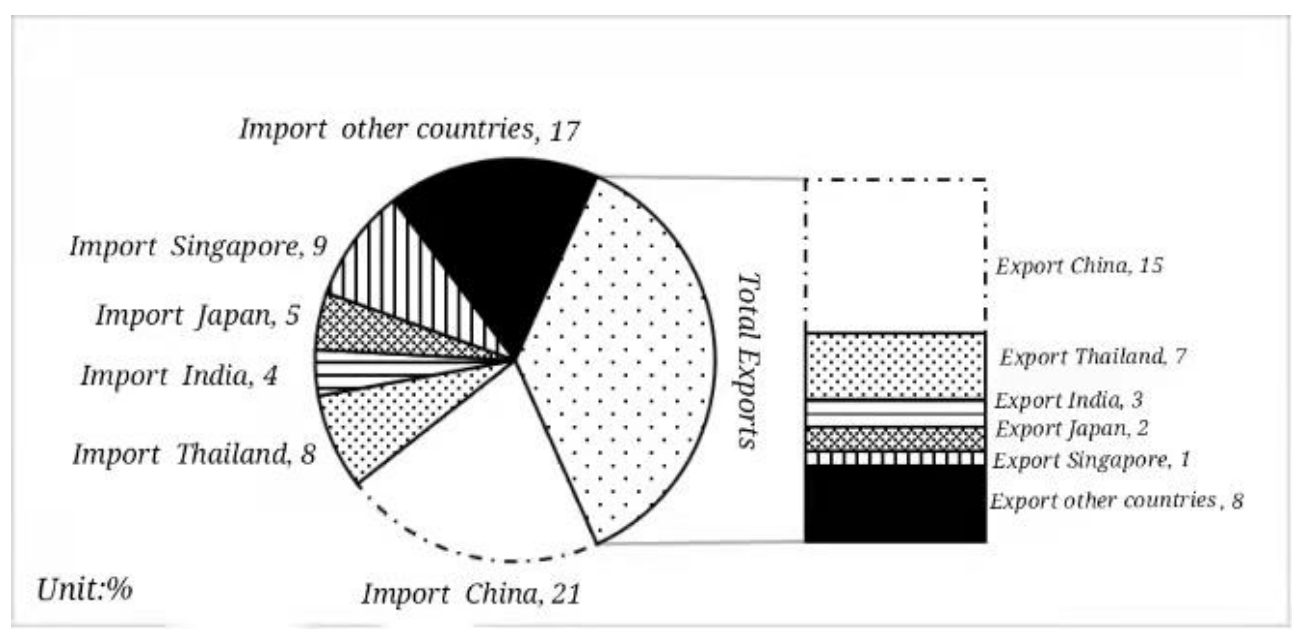

Figure 3 A comparison of total imports and exports in Myanmar's international trade (2017).

\subsection{Myanmar Government Is Actively Building Border Ports and Attracting Investment}

Myanmar currently has both official and unofficial cross-border trade ports with neighboring China, Thailand, India and Bangladesh 6. Global New Light of Myanmar, June 6, 2016, reported that according to the Myanmar government's Second Five-Year Plan for National Development (FY2016-2017 to FY2020-2021), seven new border trade ports will be opened in cross-border areas, including the $\mathrm{Wa}$ region, to promote cross-border trade with neighboring countries such as China, India and Thailand. As of 2019, Myanmar has 18 official cross-border trade ports, including six from China, seven from Thailand, two from India, two from Bangladesh and one from Laos. In addition, there are two unofficial cross-border trade ports between Myanmar and China, three between Myanmar and Thailand, and one between Myanmar and India. The official cross-border trade port between Myanmar and China is: 105 Mujie Border Trade Zone, Shan State (Muse 105th Mile, January 12th, 1998), clear Water River in Shan State (Chinshwehaw, October 19th,2003),Laiki, Kachin State (Lweje, August 23rd,1998), Shan kengtung (Keng Tung), Kachin State (Laiza, December 25th,2003), Gambay, Kachin State (Kan Pike Tee). In the 2017-2018 fiscal year, the trade volume of Mjie port was US \$5.83 billion, ranking first, with Qingshuihe port US $\$ 570$ million, Laiji port US

6. Myanmar-China border trade rises in FY 2016-17. Asia Pacific Edition, Xinhua News, 2017-04-20. An (Ed.)
\$230 million, Ganbaidi port US \$120 million and Jingdong port US \$02 million7.

While vigorously developing port construction, the government of Myanmar has announced dutyfree areas for investment in order to attract investment. Myanmar Global New Light News, March 3, 2017: According to the development level of different regions, the investment commission of Myanmar has divided the country into three regions: developed regions, relatively developed regions and underdeveloped regions. Investors in different regions are entitled to different years of income tax exemption. Among them, investment in 46 developed townships will be exempted from income tax for 3 years, investment in 92 more developed townships will be exempted from income tax for 5 years, and investment in 166 backward townships will be exempted from income tax for 7 years.

\subsection{Cross-border Agricultural Economic Cooperation Between Yunnan and Myanmar Is the Main Carrier of China-Myanmar Economic Cooperation}

Yunnan is the only province bordering on Myanmar. Mountain areas account for $94 \%$ of the total area, and 8 cross-border prefectures account for $51 \%$ of the total area of 1.95 million hectares and $40 \%$ of the total population of 19.26 million. However, more than $80 \%$ of the forest resources

7. Take the express train of the construction of ChinaMyanmar Economic Corridor -- Border trade between Yunnan and Myanmar has achieved remarkable results and cooperation areas have continued to expand. www.yunnan.cn, 2019-02-18. 
and animal and plant species of the whole province are concentrated in Yunnan. At the same time, the 25 counties under its jurisdiction have 11 national ports, 16 ethnic groups live across the border, and four major cross-border rivers run through them. It borders 32 counties of Myanmar, Laos and Vietnam, covering a land area of nearly 20 million hectares and involving a cross-border population of more than 10 million. As an important land passage from China to South and Southeast Asia, the economic and trade exchanges, cultural exchanges and agricultural production in Yunnan have been cross-border since ancient times. Affected by two kinds of resources and two markets, Yunnan is not only an important cross-border open area, but also an important cross-border mountainous area in Yunnan and even China. From 2015 to 2018, Yunnan's share of China's total imports from Myanmar increased from $61 \%$ to $76 \%$, while its share of total exports remained at about $30 \%$. Therefore, Yunnan-Myanmar cross-border agricultural economic cooperation is the main carrier of China-Myanmar cross-border agricultural economic cooperation.

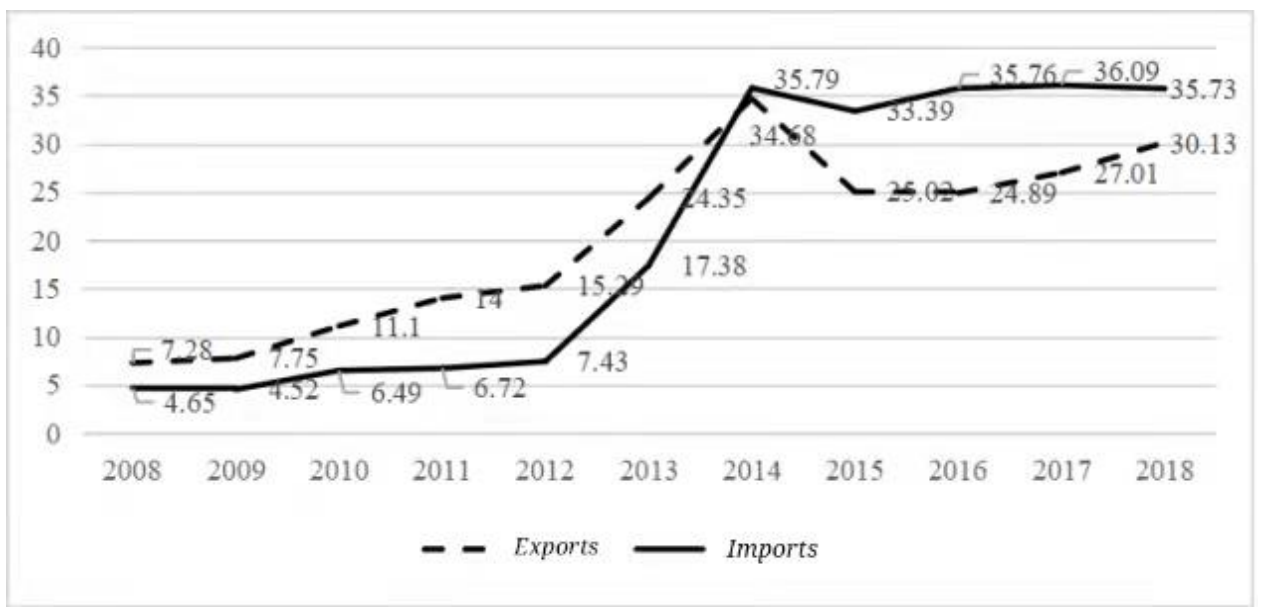

Figure 4 Border trade import and export volume between Yunnan Province and Myanmar (unit: \$100 million).

The trade between Yunnan and Myanmar has always been the main object of the trade activities between Yunnan and Asian countries. The import and export trade between Yunnan and Myanmar has a political effect on the economic growth of Yunnan and has a large export. The improvement of comprehensive logistics efficiency has significantly promoted the development of trade between Yunnan and Myanmar (ZHANG Mei, 2014; HUANG Jie, 2017). "Figure 4" shows that the import and export volume of border trade between Yunnan and Myanmar have been at a relatively high level in the past decade, In particular, from 2012 to 2014, the export volume rose rapidly. However, due to the economic downturn in Myanmar, the export volume began to decline from 2014. However, in the change of Yunnan's total import and export volume to Asia from 2015 to 2018, Myanmar's export volume still showed a slight upward trend from $20 \%$ to $29 \%$, mainly electric power and mechanical and electrical products, etc. However, due to the influence of Myanmar's export restrictions on logs, Myanmar's import volume dropped from $61 \%$ to $26 \%$. a Sources: Statistical Yearbook of Yunnan Province》2009-2019

Meanwhile, from 2010 to 2017, the trade volume of agricultural products between Yunnan and Myanmar increased from 296 million US dollars to 320 million US dollars, Although the share of trade declined from $16.8 \%$ to $5.1 \%$, the total volume continued to grow, which will further consolidate the foundation for agricultural and economic cooperation.

\section{CONCLUSION}

China is the largest trading partner of Myanmar. Agricultural products are one of the main foreign exchange earning products exported by Myanmar to China, and they are also the main products that Myanmar hopes to narrow its trade deficit. The construction of "South Asia and Southeast Asia Radiating Center" in Yunnan is an important fulcrum to serve the construction of "One Belt And One Road" and the main carrier of Myanmar-China cross-border trade. Therefore, the enhancement and improvement of Yunnan-Myanmar agricultural trade should be the focus of Myanmar-China trade. China has been working hard to solve the problems 
existing in bilateral agricultural trade, and has taken various measures in terms of quotas, product inspection, smooth customs clearance and technical support to Myanmar. The following is a summary of Myanmar's views:

\subsection{Products Standards}

Myanmar's agricultural exports to other countries are mostly raw materials with lower added value, while its imports are mostly valueadded products with high prices. Myanmar can adjust its trade balance by improving its production technology and developing value-added products, but the goods to be exported must be of standard quality for the market, agricultural exports from Myanmar, such as rice, corn and watermelons, are required to meet quality standards for the Chinese market, legumes must meet Indian standards (the author think Myanmar's non-GM soybean market has huge potential, so it should meet Chinese standards). Therefore, the standardization of crop quality and product quality in Myanmar is urgently needed to secure its market.

\subsection{Port Construction}

The government will open seven trade ports in the second five-year plan, but some remain unofficial. Myanmar and its neighbouring countries have successively officially opened all trading ports in accordance with the actual situation in order to eliminate illicit cross-border trade and convert it all into legal trade. At the same time, in order to facilitate trade between Myanmar and its neighbours, it is important to ensure that all trading ports are legally open and to harmonize the quantity and quality of goods traded between the two countries.

\subsection{Information Sharing}

In order to avoid trade corruption due to demand and supply imbalances, as well as surprises and challenges in the trade process, it is essential to meet consumer preferences, market demand, supply potential, and information exchange. Especially during the COVID-19 period, the timely and smooth exchange of information is more conducive to the sustained development of bilateral agricultural science and technology cooperation.

\section{AUTHORS' CONTRIBUTIONS}

Pei Mao is responsible for experimental design and translation; Yan Zhang analysed data; Lu Feng wrote the manuscript; Pau Sian Kam contributed to revising and editing.

\section{REFERENCES}

[1] Koji KUBO, 2016. Myanmar's Cross-border Trade with China: Beyond Informal trade. IDE Discussion paper No. 625, Institute of Developing Economics, Jetro, Japan.

[2] Li T. Boundary Effect of Chinese CrossBorder Economic Cooperation [J]. Economic Geography, 2015.

[3] Marcela Şlusarciuc. The Economic Potential of Crossborder Areas. Opportunities and Threats $[\mathrm{J}]$. Procedia Economics and Finance, 2015, 32:801-808.

[4] Niebuhr A., Stiller S., Integration effects in border regions: a survey of economic theory and empirical studies, Hamburgisches Welt Wirtschafts Archiv (HWWA) discussion paper, 2002.

[5] Perkmann M., Cross-border region in Europe: significance and drives of regional crossborder cooperation, European Urban and Regional Studies, 10(2), pp 153-171, 2003.

[6] Ratti R., Reichman S. Europe on the Move: Recent Development in European Communications and Transport Activity Research. Chapter 6. Spatial Effects of Borders: An Overview of Traditional and New Approaches to Border Region Development [M]. Avebury Ashgate Publishing ltd, 1993.

[7] Tsuneishi T. Development of Border Economic Zones in Thailand: Expansion of Border Trade and Formation of Border Economic Zones. IDE Discussion Papers 153, Institute of Developing Economies, Japan External Trade Organization (JETRO).

[8] Li J, Xia J, Lin Z. Cross-border acquisitions by state-owned firms: How do legitimacy concerns affect the completion and duration of their acquisitions? [J]. Strategic Management Journal, 2016.

[9] Duan Haibo. Development and Countermeasures of Myanmar Border Trade under the Background of "One Belt And One 
Road" Strategy [D]. Minzu University of China, 2018.

[10] Huang Jie, Bai Jieyi, Wang Xiaoteng, Liu Mingduo. Study of Yunnan-Myanmar Trade Effect on Yunnan's Logistics Efficiency [J]. Science \& Technology and Economy, 2017, 030(003):85-89.

[11] Liu Wu, Jin Liping. The Problems Existing in the China-Myanmar Agricultural Trade and Some Considerations [J]. Indian Ocean Economic and Political Review, 2016(6).

[12] Wang Jiejia. SWOT analysis of ChinaMyanmar industrial cooperation under the background of "One Belt And One Road" [J]. China Economic \& Trade Herald, 2018, 000(020):17-18.

[13] Wen Guoquan, Wei Mi etc. Analysis of the current situation of agricultural science and technology development in Myanmar and international cooperation in agricultural science and technology between China and Myanmar [J]. Journal of Southern Agriculture, 2019(6):1392-1398.

[14] Zhang Mei. An empirical study on the relationship between Myanmar trade and Yunnan economic growth [J]. Knowledge Economy, 2014(14): 92-93.

[15] Gao Cheng, Wang Zhen. Analysis of China's Institutionalized Strategic Planning and Management of Neighboring Countries -Case Studies of China--Myanmar Economic Corridor [J]. Southeast Asian Studies, 2020(1):1-19. 